\title{
Akerlof, George A. and Shiller, Robert J.: Phishing for phools: The economics of manipulation and deception
}

\section{8 pp. Princeton University Press, 2015. Hardcover, \$24.95}

\author{
Carl Christian von Weizsäcker ${ }^{1}$
}

Published online: 29 January 2016

(C) The Author(s) 2016. This article is published with open access at Springerlink.com

In this book two leading economists provide, what I would like to call: The General Theory of Deception, Interest and Money. Transgressing established behavioral economics they develop the following general principle: whenever people do not act in their own best interest there will be others who exploit the profit opportunities arising out of such irrational or uninformed behavior. Wherever there are fools ("phools") there are fishers (phishers) who "phool" them. There arises then a "phishing equilibrium". The policy conclusion is that government should step in to avoid such unfortunate outcome of the market economy.

The book appeals to common sense by describing a large number of cases in which the "phishing equilibrium" prevails. One class of such cases is "addiction": addiction to smoking, to alcohol, to gambling, to drugs, to Facebook etc. According to the Akerlof-Shiller anthropology human behavior is governed by two "persons": the rational forward looking one, and the "monkey" on the other's shoulders; the latter striving for immediate satisfaction of wants. Often then the "monkey" on the shoulders wins in a conflict situation - and the agent disregards the future costs of giving in to some vice. Behavioral economics has taken account of that-and has provided answers, like for example the "nudging" philosophy. "Libertarian paternalism" is the slogan. Akerlof-Shiller now focus on the supply side of vice goods: the cigarette industry, the suppliers of alcoholic beverages, the gambling casinos, the drug dealers, the men and women who have developed Facebook. The concept of the phishing equilibrium is important because of its consequences: it is not so much the bad character or the crimes of the suppliers of vice goods which are the problem. For, if the present suppliers were absent, other suppliers would take their place; and the world would not have

\footnotetext{
Carl Christian von Weizsäcker weizsaecker@coll.mpg.de

1 Max Planck Institute for Research on Collective Goods, Bonn, Germany
} 
changed very much. Indeed: food retailers put the candy bars near the cash counter at the exit to seduce their customers (and their children) to buy these sweets, which cause bad teeth and contribute to obesity. But, a food retailer who does not comply with these "revealed preferences" of his customers is likely to go under in the fierce competition among food retailers. Competitive pressure forces suppliers to participate in the "phishing" game.

Apart from the monkey image of the split human character there is the other basic ingredient of the Akerlof-Shiller description of human nature: storytelling. People decide between alternatives on the basis of "stories" in their heads. In a world of an uncertain future the expected results of any decision are informed by the stories in the minds of the decision makers. But these stories might be changed by those who expect to profit from a shift to a different story. The decisions of people to a large extent are influenced by stories which originate from those phishers. This story based decision making is particularly relevant for consumers who are not well informed about the products offered to them. Advertising and other marketing instruments are designed to change the stories in the heads of consumers.

The financial sector is full of products which supposedly help the investor to cope with risk and uncertainty. One example of the many discussed in the book is the "junk bond revolution" brought about by Michael Milken. Milken discovered that the returns on junk bonds were substantially larger than is justified by the risk associated with them. He then developed a gigantic business in junk bonds. And from this came new forms of financing hostile takeovers. In the end many large bankruptcies were the consequence. What had happened was the unnoticed change in the character of junk bonds. Earlier these were former investment grade bonds of debtors who had incurred unexpected losses. After Milken junk bonds were bonds issued as junk bonds from the very beginning; and these came with substantially higher risk of default. But Milken and associates successfully told the old story about the profitability of junk bonds which was an incorrect story for the newly issued junk bonds. A lot of white collar crime was also involved in this Milken business scheme. On a more general level the two authors argue in favor of substantially larger budgets for the Securities and Exchange Commission which is responsible for the regulation of the financial markets.

Akerlof and Shiller devote part of the book to describe episodes of the government regulation history. Here they find unknown heroes whose private initiatives eventually led to beneficial government regulation. The formation and growth of the Food and Drug Administration is such a story.

The two authors again and again emphasize that they acknowledge the productive and beneficial effects of markets. But they do support many instances of government paternalism in the form of prohibitions, taxes or subsidies. They strongly oppose the idea of complete market laissez faire, of market fundamentalism.

What do we make of it? Let me try to give a frame to the General Theory of Deception, Interest and Money. It is a theory which wants to use the market mechanism selectively, and not universally. Clearly it is not libertarian. On the other hand not everything should be done by the government. The framework I like to suggest is the idea of "piecemeal engineering" as it has been proposed by Karl Popper in his book "The Open Society and its Enemies". This is an approach in social philosophy; Popper 
developed it in explicit opposition to totalitarian utopia-driven approaches, like-for example-Stalinism. The proposal is to accept any given status quo as the starting point of thinking about society. From here incremental changes are being proposed that are considered to be improvements. If such partial changes of the social state of affairs eventually turn out to be improvements one maintains them; if not, they are rescinded. It is, thus, very much a philosophy of trial and error. From the normative point of view the Popper approach means that the actual status quo is provisionally legitimized. Any disgrace observed in the status quo will only be de-legitimized if and to the extent that an alternative way of doing things is considered an improvement. This improvement is then implemented-and one then observes whether it really turns out to change the world for the better.

In a democracy there will be controversy about the question whether any given proposal for change can be seen as an improvement. Debate and majority decision will determine whether any proposed change of affairs will be implemented.

Within this framework of democratic piecemeal engineering there is the general, but provisional, presumption that actions of citizens correspond to their interests, i.e. correspond to their preferences. To the extent that these actions observe the legal and economic constraints of the citizen they are quasi automatically socially legitimized, because they are a consequence of the citizen's decision. This is, I believe, the basic philosophy of the principle of revealed preference, and thus of cost-benefit analysis. Freedom of choice of citizens implies the idea that people act in their own interest. Preferences are then the concept by which the idea of liberty enters into the modelling set-up of the economist.

This concept of liberty means the following: the causal chain leading up to the particular decision of the citizen is irrelevant for the social legitimacy of that decision. An example is given by elections: the vote of any citizen counts irrespective of the causal chain that makes him or her cast the ballot for any particular candidate.

Causal analysis may override the provisional legitimacy of any given class of decisions by the citizens. This is then the case when the status quo is considered disgraceful in some respect. Thus, the freedom to advertise cigarettes becomes a disgrace, once scientific evidence shows that cigarette smoking raises the risk of death by lung cancer. And then the legislator steps in to regulate the marketing of cigarettes.

Looking at the role of markets and paternalistic government intervention in this way we observe the generally familiar pattern of "rule and exception". Freedom of action is the rule and government paternalism is the exception. Regulation by government then is always local intervention, i.e. intervention in the spirit of exceptionalism.

But, of course, given human nature as it is, there may be myriads of exceptions to the general rule of freedom of action or freedom of speech. Nevertheless the general principle of criminal law may also apply here: "in dubio pro reo". For the government to change a phishing equilibrium by regulation it basically needs proof of the causal chain leading up to a disgraceful state of affairs.

It is my impression that the Akerlof-Shiller book is intended to improve the world very much in the spirit of piecemeal engineering. Thus the following caveats may not really be a critique of the book, but rather points of clarification.

The first and obvious caveat is the following observation: there is a lot of "phishing" going on in the education of children by their parents and by their teachers. We may see 
this as phishing with a negative sign, preventive "un-phishing", so to speak. Parents incur costs rather than profits to lead their children to a better position in the world. The reward for these costs only comes because parents love their children: altruism. On a more general level: there is a lot of influencing other persons going on in society. And, to the extent that we believe in a free civil society, we approve of the principle that interpersonal influences are legitimate forms of social intercourse. Given that people disagree about the best government policy and given that we accept the provisional nature of any majority opinion there must be the benefit of doubt against government intervention into processes of interpersonal influences.

This caveat is reinforced by a second one: distrust in government activity. Or in economic jargon: "public choice". Akerlof and Shiller rightly, I believe, are critical of the public choice philosophy which treats civil servants and politicians as simple profit maximizers. Nevertheless, as they themselves insist, competition forces actors in a particular phishing equilibrium to join the crowd of phishermen. Applied to politics, competition in this field may force politicians to become vote-maximizers, as described by the public choice school. Akerlof and Shiller provide examples of political phishing which keeps government from regulating where it ought to have regulated. But the opposite may also happen: if the government imposes import duties to satisfy the demands of politically well-organized parts of the electorate, this may be to the detriment of welfare. The phishing or rent seeking in politics may cut either way: too much or too little government regulation. And here we may remind ourselves of an announcement by the Roman historian Tacitus: "Perditissima republica plurimae leges." (It is the most rotten republic which has the largest number of laws on the books).

A third caveat is this one: in any given instance of phishing there are not only phools and phishers; there are also bystanders; let me call them "philosophers". Commercial television lives on advertising revenue from "phishers" who want to implant sales-enhancing stories into the minds of "phools". But there is likely to be a group of television viewers who lack that particular monkey on their shoulders and who therefore are not directed to buy more product from the "phishers"; but they benefit from this "phishing" by TV-advertising, because they enjoy TV-content paid for by the advertising revenue.

Or to give another example: Akerlof and Shiller quote a paper by Stefano DellaVigna and Ulrike Malmendier. These authors found out that many customers of health clubs opt for a payment contract which then turns out to be more expensive than another one they could have chosen. The reason seems to be that at the time of signing the contract they overestimate the future frequency of making use of the health club facilities. Obviously, other things equal, health clubs profit from the "wrong" choice of contract. But other things are not equal, because there is competition among health clubs. So we expect health clubs to break even-approximately. But then the health clubs' profit from a "wrong" choice of payment contract by some customers is passed on to those customers who take the "right" payment contract-in the form of lower prices. In other contexts this pass on result among different groups of customers has been called the "waterbed-effect".

Should the government intervene in the health club case? No! One may cast doubt on the efficiency of the market result: after all, prices here do not exactly reflect the social 
cost of providing the product. But, looking at it in a more encompassing manner, the market result may be more efficient than any alternative due to government intervention could be. In this phishing equilibrium the phools subsidize the philosophers. Is this so bad? Doesn't this provide an incentive to behave like a philosopher rather than a phool? Moreover, in terms of the long run effects on health, the lack of will-power among the phools is partly compensated by the fact that in their choice of payment contract they opt for a zero marginal cost for visiting the health club. And indeed, the "phools" here may be aware of this effect; which makes them look not so "phoolish" after all.

More generally: we have learned from our founder Adam Smith that the division of labor is the main source of our material wealth. On the other hand, our tax system basically boils down to a taxation of the system of the division of labor, which is market driven. And the marginal tax rate is quite high, perhaps 50 percent. As we look at phishers and phools we get the impression that the phools have to work longer hours to be able to pay for all these gadgets their phishers succeed in selling them. But then, for a given level of government expenditure, tax rates on the division of labor can be lower than they would have to be without all these phishing equilibria. Doesn't this imply that the by-standing philosophers benefit from these phishing expeditions, because they pay lower taxes for the same public goods?

Of course, I know what Akerlof and Shiller can answer here: concerning government expenditure other things are not equal. The sum of phishing equilibria may cause so much damage to phools that the government may have to spend more money to help them out of a disgraceful state of affairs.

A fourth caveat: Akerlof's fame (and the Nobel Prize awarded to him) grew in particular out of his paper on "The Market for Lemons". There he showed how incomplete information among customers concerning the quality of a product could lead to a total collapse of that particular market. Yet, as Hayek had pointed out two decades earlier, society has developed a mechanism which can partly solve this problem: reputation. A seller may resist the temptation to lie to the customer concerning the product quality. The reason can be his concern for maintaining his reputation as an honest merchant. His reputation may allow him to charge a reputation margin on his product which is high enough to withstand the temptation of pretending better product quality than is actually the case. Akerlof and Shiller provide examples for phishing which is associated with a run-down of one's reputation. So it is clear that the reputation mechanism does not solve all problems. But there is little doubt that it is highly important in economic live.

So, before government intervenes in any particular case, one should ask the question: cannot reputation mechanisms solve the problem—-perhaps not immediately, but in the long run?

In the General Theory of Employment, Interest and Money, Keynes introduced the concepts of effective demand and of an unemployment equilibrium. He recommended government deficit spending to change the equilibrium for the better. Economic policy has adopted the idea of stabilizing fiscal policy. But then the possibility of running government deficits was abused; and we ended up with inflation and unemployment at the same time ("stagflation"). Nevertheless fiscal policy, at the least in the form of 
government expenditure as a built in stabilizer remains a valid contribution to overall welfare.

Here, in The General Theory of Deception, Interest and Money, Akerlof and Shiller introduce the concept of phishing equilibrium. The authors recommend government regulation to reduce the amount of phishing in the economy. But there is the danger of an abuse of such government regulating power. So, the general idea of government action against phishing remains valid; but we have to be on the guard against an excessive use of such government power.

Open Access This article is distributed under the terms of the Creative Commons Attribution 4.0 International License (http://creativecommons.org/licenses/by/4.0/), which permits unrestricted use, distribution, and reproduction in any medium, provided you give appropriate credit to the original author(s) and the source, provide a link to the Creative Commons license, and indicate if changes were made. 